\title{
THE PROBLEMS IN LEGAL ASSESSMENT AND EXPERT STUDY OF EDIBLE POPPY
}

\section{Komarov I. M.}

The article analyzes legal sources regulating the legal status of edible poppy, which is often used as an object for trespasses involving illegal trafficking of narcotic substances. It deals with specific issues of importance for correct application of the criminal law with regard to prosecuting criminals, including the issues of an expert study of edible poppy in order to identify the features warranting it as an object of trespassing. The article suggests unifying all the notions related to the genus Papaver (somniferum, opium, etc) that can be used in forensic and investigation practice. The author believes that the contents of the Russian standards containing all the requirements to the edible poppy seeds (including imports) must be brought into conformity with the international and Russian legislation, while methodological recommendations regarding the study of edible poppy seeds in forensic examinations should be unified and meet the law in force (that should be unified as well).

Keywords: criminal and legal description of drug-related offenses, examination of edible poppy, edible poppy.

В. М. Шевчук, професор кафедри криміналістики Національного юридичного університету імені Ярослава Мудрого, доктор юридичних наук, доцент, заслужений юрист України

\section{РОЗВИТОК НАУКОВИХ УЯВЛЕНЬ ПРО ТАКТИЧНІ ОПЕРАЦЇ̈}

Досліджено історію виникнення та становлення криміналістичної категорії «тактична операція». Генеза тактичних операчій досліджується за двома напрямами: теоретичним (як наукова категорія криміналістики) $i$ практичним (як засіб практичної діяльності слідчих органів). Вивчення історії тактичних операцій здійснюється з урахуванням чинників-детермінантів, які вплинули на процес виникнення й формування иієї криміналістичної категоріі. Запропоновано перспективні напрями подальших наукових досліджень розглядуваної проблематики.

Ключові слова: генеза, тактичні операції, тактичні комбінації, історія тактичних операцій, еволюційний шлях розвитку тактичних операцій, криміналістична теорія тактичних операщій.

Дослідження історії виникнення й становлення, сучасного стану та перспектив розвитку тактичних операцій необхідні для формування концепції цієї криміналістичної категорії, визначення іiї природи, сутності, теоре-

(C) Шевчук В. М., 2015 
тичного значення й практичної спрямованості. Жодне суспільне явище не можна вивчити та зрозуміти без урахування умов і особливостей його виникнення й розвитку, тобто у відриві від його історії. Його можна розкрити та зрозуміти, якщо з'ясувати, у яких умовах і за яких обставин воно виникло, яким було в минулому, які еволюційні етапи історичного розвитку пройшло. Тільки так відкриється можливість визначити, чим воно є сьогодні та як буде розвиватись у майбутньому ${ }^{1}$. Тому вивчення й розроблення тактичних операцій має здійснюватися на підставі загальнотеоретичних підходів, що забезпечують обгрунтування фундаментальних положень (генезу, сутність, факт, гіпотезу та ін.) цієї криміналістичної категорії.

На наш погляд, дослідження генези тактичних операцій доцільно здійснювати щодо двох взаємопов'язаних аспектів - теоретичного та практичного. За першим тактичні операції розглядаються як наукова категорія криміналістики, а за другим як засіб практичної діяльності слідчих органів 3 оптимізації процесу розслідування. Крім того, це дослідження має здійснюватися 3 обов'язковим урахуванням чинників-детермінантів, які вплинули на процес виникнення й формування цієї криміналістичної категорії. Такий підхід дає можливість простежити шлях розвитку тактичних операцій з огляду на стан боротьби зі злочинністю, практику діяльності правоохоронних органів, ступінь наукових досліджень у криміналістиці. Як слушно зауважує I. О. Возгрін, принцип історизму в криміналістиці означає, що пізнання їі змісту, як і розроблення їі нових положень, повинні здійснюватися з урахуванням якісних змін, що відбувались у процесі еволюції цієї галузі наукового знання. Брак знань про генезу певної криміналістичної категорії, неповне або хибне уявлення про їі історію - найчастіші причини невдач наукових розробок, що свідчить про їх низький теоретичний рівень і показує не лише непідготовленість дослідників у галузі криміналістичного наукового знання, а й недоліки всієї методології дослідження².

Генеза тактичних операцій як динамічної системи, що розвивається, також складається із певних стадій, етапів і періодів. Слід наголосити, що на відміну від достатньо ретельного аналізу історії науки криміналістики ${ }^{3}$ пропозиції щодо періодизації розвитку тактичних операцій науковцями майже не висловлювалися, що негативно позначається на об’єктивності аналізу сучас-

1 Див.: Андреев И. Д. О методах научного познания / И. Д. Андреев. - М. : Наука, 1964. - С. 99-100.

Див.: Возгрин И. А. Введение в криминалистику: история, основы теории, библиография / И. А. Возгрин. - СПб. : Юрид. центр Пресс, 2003. — С. 83-84.

3 Див.: Белкин Р. С. История отечественной криминалистики / Р. С. Белкин. М. : НОРМА, 1999; Коновалова В. О. Історія виникнення і тенденції розвитку криміналістики на Україні / В. О. Коновалова // Вибрані твори. — Х. : Апостіль, 2012. С. 29-32; Криминалистика / под ред. В. А. Образцова. - М. : Юристь, 1996; Хижняк Д. С. Процессуальные и криминалистические проблемы развития тактики следственных действий / Д. С. Хижняк. - М. : Юрлитинформ, 2004; Яблоков Н. П. О проблемах преподавания криминалистики и подготовки специалистов-криминалистов в юридических вузах России в современных условиях / Н. П. Яблоков // Вестн. Моск. ун-та. Серия 11. Право. — 2000. — № 1. - С. 55-56 та ін. 
ного стану цієї категорії та прогнозуванні іiі перспектив. 3 огляду на викладене вбачається доцільним в історії розвитку тактичної операції як наукової криміналістичної категорії й комплексного тактичного засобу практичної діяльності в кримінальному провадженні виділяти п'ять етапів:

1) зародження перших прийомів і засобів розслідування, накопичення початкового досвіду їх комплексного застосування в боротьбі зі злочинністю (з давніх часів - до кінця XIX ст.);

2) виникнення криміналістики як самостійної галузі наукового знання, накопичення емпіричного матеріалу й поява перших уявлень про тактичні операції (кінець XIX ст. - 30-ті рр. XX ст.);

3) формування окремих криміналістичних теорій і створення передумов для виникнення ідеї тактичних операцій (40-60-ті рр. XX ст.);

4) поява криміналістичної категорії «тактична операція», початок розроблення іiї наукової концепції (70-90-ті рр. XX ст.);

5) подальше формування криміналістичної теорії тактичних операцій, побудова та впровадження систем типових тактичних операцій у методиках розслідування окремих видів злочинів (середина 90-х рр. ХХ ст. - до сьогодні).

Історія зародження перших прийомів і методів протидії злочинності, накопичення початкового досвіду їх застосування на практиці своїми коренями сягає в давнину й тісно пов'язана з виникненням спеціальних прийомів і засобів ведення розслідування, у тому числі й комплексного спрямування. Як зазначає В. Ю. Шепітько, поява порушників законів зумовила потребу введення спеціальних правил і методів щодо розкриття й розслідування злочинів $\mathrm{i}$ встановлення злочинців ${ }^{1}$. Р. С. Бєлкін зауважував, що вже у священних книгах різних народів можна зустріти висвітлення допиту, обшуку, упізнання. Ці прийоми згадувались і в пам'ятках давнього права різних країн².

На переконання I. М. Комарова, уявлення про криміналістичні (тактичні) операції як систему слідчих, оперативно-розшукових та інших дій, спрямованих на вирішення окремих тактичних завдань розслідування, зародилися достатньо давно. Процес формування теорії й практики цих операцій має свою тривалу історію. В окремих джерелах, законодавчих пам'ятках $€$ згадки про комплексне вирішення завдань досудового провадження, схоже із сучасними уявленнями про тактичні операції․ Так, за часів Руської Правди (XI-XIII ст.) засобами розшуку підозрюваних осіб у вчиненні злочину були «заклич», «звід», «гоніння сліду» ${ }^{4}$. На нашу думку, це були перші паро-

${ }^{1}$ Див.: Шепітько В. Ю. Історія криміналістики / В. Ю. Шепітько // Криміналістика : підручник / за ред. В. Ю. Шепітька. — [4-те вид., перероб. і допов.]. — Х. : Право, 2008. - С. 28.

2 Див.: Белкин Р. С. История отечественной криминалистики / Р. С. Белкин. М. : Норма, 1999. - С. 1.

3 Див.: Комаров И. М. Криминалистические операции досудебного производства в системе криминалистики : монография / И. М. Комаров. - М. : Юрлитинформ, 2010. - C. 8.

4 Див.: Зимин А. А. Памятники русского права / А. А. Зимин. - Вып. 1: Памятники права Киевского государства X-XII вв. / под ред. С. В. Юшкова. - М. : Гос. изд-во юрид. лит., 1952. - С. 152; Правда Русская : учеб. пособие / под ред. Б. Д. Грекова. — Л. : АН СССР, 1940. 
стки комплексних тактичних засобів у розслідуванні злочинів, образно кажучи, «прообрази» криміналістичних комплексів організаційно-тактичного спрямування. Зокрема, «гоніння сліду», тобто переслідування по гарячих слідах, можна оцінювати як комплексне застосування засобів кримінального переслідування, що деякою мірою подібні до сучасних уявлень про тактичні операції, наприклад, таким як «Переслідування злочинця по гарячих слідах», «Установлення особи, яка вчинила злочин», «Розшук і затримання підозрюваного» та ін.

За часів запорізького козацтва (XV-XVIII ст.) у ході розшуку злочинців застосовувалися такі комплексні засоби, як розвідувальне опитування, опитування населення, адміністрації, духовних осіб, «трус села» (розшук і обшук), оперативне провадження, внутрішньокамерна розробка, оперативна комбінація та інші, а також ті, витоки яких сягають Руської Правди, - «гоніння сліду», або «шляхування коней»; «заклич», або «обволання» ${ }^{1}$.

Нагадують деякою мірою тактичні операції (комбінації) й дії, які зустрічаються в законодавчих актах XVI ст. - часів царювання Івана III, приміром, прийоми допиту «злодія, затриманого з речовим доказом»². Зустрічаються й інші свідчення застосування системи дій і заходів, подібних до тактичних операцій, спрямованих на комплексне вирішення певних завдань розслідування.

Слід звернути увагу й на те, що деякі рекомендації з комплексного застосування спеціальних прийомів і засобів розслідування в рамках чинного кримінального судочинства сягають своїми коренями в першу половину XIX ст. (наприклад, про послідовність дій слідчого при розслідуванні різних видів злочинів відповідно до зводу законів, розроблених на основі емпіричних знань і життєвого досвіду).

Саме в цей час з'являються перші наукові праці, у яких учені намагаються викласти аргументовані поради для практиків. Так, у Німеччині на межі XVIII-XIX ст. серед перших найбільш відомих учених, які присвятили свої праці вивченню практики розкриття й розслідування злочинів, слід назвати Л. фон Ягеманна, Г. Ціммерманна, Г. Ортлоффа, В. Штібера ${ }^{3}$ та ін.;

1 Див.: Бойко I. Й. Держава і право Гетьманщини : навч. посібник / І. Й. Бойко. - Львів : Світ, 2000; Пашук А. И. Суд і судочинство на Лівобережній Україні в XVII-XVIII столітті (1648-1762) / А. Й. Пашук. - Львів : Вид-во Львів. ун-ту, 1967; Яворницький Д. І. Історія запорозьких козаків : у 3 т. / Д. І. Яворницький. — Львів : Світ, 1992. - Т. 3. - С. 165.

2 Див.: Соловьев С. М. Сочинения: в 18 кн. - Кн. 3. Т. 5, 6: История России с Древних времен / С. М. Соловьев ; отв. ред. М. Д. Ковальченко, С. С. Дмитриев. М. : Мысль, 1989. - С. 332.

3 Див.: Jagemann L. H. F. Handbuch der gerichtlichen Untersuchungskunde / L. H. F. Jagemann. — L. B. Frankfurt a Main : Verlag Rettembeil, 1838. — 772 s.; Zweiter Band, 1841. — 994 s.; Zimmermann G. Die Deutsche Polizei im neunzehnten Jahrhundert / G. Zimmermann. - Hannover : Verlag Schluter, 1845. — 645 s.; Dritter Band, 1849. 1345 s.; Ortloff H. Lehrbuch der Kriminal-Polizei auf Grund der deutschen Reichsgesetze / H. Ortloff. - Leipzig : Verlag R. Reisland, 1881. - 286 s.; Stieber W. Praktisches Lehrbuch der Kriminal-Polizei / W. Stieber. — Berlin : Verlag Hahu, 1860. — 223 s. 
серед вітчизняних правників - роботи М. А. Орлова, Я. І. Баршева, Д. Р. Долгова, О. А. Квачевського та ін.

Зокрема, М. А. Орлов надає низку рекомендацій щодо тактики проведення окремих слідчих дій - допиту свідків, очної ставки, пред’явлення для впізнання тощо ${ }^{1}$. Проблематика проведення обшуку, огляду, допиту, очної досліджена Я. І. Баршевим².

Серед праць цього періоду заслуговує на особливу увагу робота Д. Р. Долгова, яка присвячена окремим питанням організації розслідування злочинів і являла собою своєрідний посібник для слідчих з організації розслідування злочинів. Особливий інтерес становить глава 4 , у якій розглядаються питання тактики проведення окремих слідчих дій - загальних форм проведення слідства ${ }^{3}$.

У роботі О. А. Квачевського викладаються прийоми проведення окремих слідчих дій, серед яких уперше в правовій літературі виділяється група першочергових слідчих дій, до яких автор відносить огляд, освідування, виявлення зовнішніх предметів злочину шляхом обшуку, виїмки, збирання речових доказів ${ }^{4}$.

Отже, у середині XIX ст. (як до судової реформи у Росії, так і після неї) зусиллями науковців та практиків розробляються рекомендації з комплексного застосування прийомів провадження окремих слідчих дій і оперативно-розшукових заходів зі встановлення злочинця, що інколи нагадували сучасні уявлення про тактичні операції.

Подальше формування та впровадження в судово-слідчу практику комплексів слідчих дій і оперативно-розшукових заходів тісно пов'язані із виникненням та становленням криміналістики як самостійної галузі знань. На цей процес вагомий вплив мали праці таких видатних науковців, як Г. Гросс, А. Вайнгард, В. Штібер, Г. Шнейкерт, А. Гельвіг, Е. Анушат та ін. ${ }^{5}$ Так, у

${ }^{1}$ Див.: Орлов Н. А. Опыт краткого руководства для произведений следствий с показанием приличных узаконений / Н. А. Орлов. - М. : Универ. тип., 1833.

2 Див.: Баршев Я. И. Основания уголовного судопроизводства с применением к российскому уголовному судопроизводству / Я. И. Баршев. - СПб., 1841.

3 Див.: Долгов Д. Р. Основные формы уголовных следствий, вообще принятые при их производстве / Д. Р. Долгова. - СПб., 1846.

${ }^{4}$ Див.: Квачевский А. А. Об уголовном преследовании, дознании и предварительном исследовании преступлений по судебным уставам 1864 г. : в 2 ч. / А. А. Квачевский. - СПб. : Тип. Ф. С. Сущинского, 1867. - Ч. 2.

5 Див.: Гросс Г. Руководство для судебных следователей как система криминалистики / Г. Гросс. - Новое изд., перепеч. с изд. 1908 г. - М. : ЛексЭст, 2002; Вайнгард A. Уголовная тактика: руководство к расследованию преступлений / А. Вайнгард ; пер. с нем. ; под ред., с прим. В. И. Лебедева. - СПб. : Вестник полиции, 1912; Штибер В. Практическое руководство для работников уголовного розыска / В. Штибер, Г. Шнейкерт ; пер. с нем. - М. : Гостехиздат, 1925; Шнейкерт Г. Тайна преступника и пути к ее раскрытию (к учению о судебных доказательствах) / Г. Шнейкерт ; пер. с нем. - М. : Право и жизнь, 1925; Гельвиг А. Современная криминалистика. Методы расследования преступлений / А. Гельвиг ; пер. с нем. ; под ред П. И. Люблинского. - М. : Право и жизнь, 1925; Анушат Э. Искусство раскрытия преступлений и законы логики / Э. Анушат. - М. : ЛексЭст, 2001. 
1898 р. світ побачила книга австрійського вченого, судового слідчого Г. Гросca, а в 1908 р. в Санкт-Петербурзі вийшов повний переклад 4-го видання цієї праці ${ }^{1}$, де автор розглядає особливості розслідування окремих видів злочинів, а також тактику проведення допиту, огляду, обшуку. Він здійснив спробу надати загальні рекомендації слідчому, виходячи зі специфіки його діяльності. У зв’язку із цим М. П. Яблоков слушно зазначає, що вже на початку своєї слідчої діяльності Г. Гросс зрозумів, що без чіткої наукової системи в діях посадовців поліції та слідчих розслідування злочинів не може бути ефективним. Для цього потрібна науково продумана система слідчих дій і нові прийоми, методи й засоби їх проведення, які спираються на останні досягнення природничо-технічних наук того часу².

Цілком очевидно, що зарубіжна криміналістична література не могла повною мірою задовольняти потреби практичних працівників. Виникає необхідність у грунтовних наукових розробках вітчизняними вченими-криміналістами, які були б засновані на емпіричних знаннях ведення боротьби зі злочинністю в інших соціально-політичних та економічних умовах і стосувалися б усіх розділів криміналістики ${ }^{3}$. До найбільш значущих перших праць слід віднести публікації таких учених-криміналістів, як С. М. Трегубов, I. М. Якимов, В. І. Громов та ін. Особливий інтерес становили пропозиції С. М. Трегубова щодо встановлення особи злочинця 4 , І. М. Якимова щодо запровадження загальної схеми розслідування ${ }^{5}$, В. І. Громова щодо обгрунтування необхідності враховування в слідчій роботі не лише техніки, а й теоретичного осмислення процесу розслідування в цілому 6 .

Підсумки наукових досліджень цього періоду висвітлені в перших вітчизняних підручниках із криміналістики, які вийшли у світ у середині $30-\mathrm{x}$

1 Див.: Гросс Г. Указ. праця.

2 Див.: Яблоков Н. П. Предисловие // Гросс Г. Руководство для судебных следователей как система криминалистики / Н. П. Яблоков. - С. Q.

3 Див.: Коновалова В. E. Некоторые вопросы истории советской криминалистики (1917-1920 гг.) / В. Е. Коновалова // Науч. конф. по работам 1955 г. : тезисы докл. - Х. : Изд-во Харьков. гос. ун-та, 1956. - С. 62-65.

Див.: Трегубов С. Н. Основы уголовной техники. Научно-технические приемы расследования преступлений / С. Н. Трегубов. - Петроград : Право, 1915; Він же. Указ. праця. - М. : ЛексЭст, 2002; Белкин Р. С. Криминалистическая энциклопедия / Р. С. Белкин. - М. : БЕК, 1997. - С. 306.

Див.: Якимов И. Н. Опыт уголовного розыска / И. Н. Якимов // Рабоче-крестьянская милиция. - 1923. - № 5-7; Він же. Вспомогательная система регистрации преступников и преступлений // Там само. - 1923. — № 6; Він же. Новости уголовной техники // Там само. - 1923. - № 10; Він же. Практическое руководство к расследованию преступлений. - М. : Изд-во НКВД РСФСР, 1924; Він же. Криминалистика. Руководство по уголовной технике и тактике / И. Н. Якимов. - М. : Изд-во НКВД РСФСР, 1925; Він же. Криминалистика, ... - Новое изд., перепеч. с изд. 1925 г. - М. : ЛексЭст, 2003.

6 Див.: Громов В. И. Дознание и предварительное следствие: методика расследования преступлений: осмотр места происшествия (сб. науч. тр.) / В. И. Громов. М. : ЛексЭст, 2003; Белкин Р. С. История отечественной криминалистики / Р. С. Белкин. - М. : НОРМА, 1999. — С. 50. 
років минулого століття. Зокрема, у підручниках 1938-1939 рр. криміналістика визначалася як наука про розслідування злочинів і в них зверталась увага на те, що всі наукові засоби й методи мають грунтуватися на принципах законності, забезпечуючи встановлення істини по справі ${ }^{1}$.

Саме в цей період вітчизняна криміналістика заявила про своє існування, а вчені-криміналісти виступали самовідданими ії пропагандистами. Як справедливо зазначали Г. І. Кочаров і М. О. Селіванов, праці цих учених мали важливе значення для наукової організації боротьби зі злочинністю, вони формували смак до наукових методів розслідування ${ }^{2}$. У роботах того часу значне місце відводилося теоретичним обгрунтуванням необхідності запровадження в практичну діяльність слідчих органів комплексних прийомів (способів) проведення розслідування, які отримали назву тактикокриміналістичних, що об’єктивно відбивало їх сутність.

3 початку 40-х - до кінця 60-х рр. минулого століття відбуваються наукові дискусії з приводу предмета, системи та природи криміналістики. Вони особливо активізуються після створення Всесоюзного науково-дослідного інституту криміналістики Прокуратури СРСР (1949 р.), який за незначний проміжок часу став загальновизнаним науковим і методичним центром із дослідження проблем криміналістичної тактики й методикиз Зокрема, на засіданні наукової ради цього інституту в 1955 р. А. І. Вінберг висловив думку, що особливим розділом криміналістики (поряд із криміналістичною технікою й методикою розслідування окремих видів злочинів) має бути криміналістична тактика, особливим ядром якої є вчення про слідчі версії

На науковій конференції в Харківському юридичному інституті в 1956 р. була заслухана доповідь В. П. Колмакова й О. Н. Колесніченка про предмет, завдання та основні положення слідчої тактики. Доповідачі запропонували віднести до предмета тактики питання планування розслідування, учення про версії, визначення найбільш доцільної послідовності проведення слідчих дій і оперативно-розшукових заходів, прийомів їх проведення, організації роботи слідчого й виховання в нього необхідних професійних якостей 5 . Про-

1 Див.: Криминалистика: техника и тактика расследования преступлений / Н. А. Бобров, А. И. Винберг, С. А. Голунский и др. ; под ред. А. Я. Вышинского. М. : Изд-во НКЮ СССР, 1938. - С. 3; Криминалистика: методика расследования отдельных видов преступлений / С. А. Голунский, Б. М. Шавер и др. ; под ред. А. Я. Вышинского. - М. : Изд-во НКЮ СССР, 1939. - С. 5.

2 Див.: Кочаров Г. Развитие советской криминалистики и ее задачи на современном этапе / Г. Кочаров, Н. Селиванов // Соц. законность. - 1968. — № 1. — С. 32.

3 Див.: Белкин Р. С История советской криминалистики. Формирование частных криминалистических теорий (1940-е - 1950-е гг.) : учеб. пособие / Р. С. Белкин, А. И. Винберг. - М. : Юрид лит., 1983. - С. 56.

4 Див.: Винберг А. И. О системе науки советской криминалистики / А. И. Винберг // Сов. криминалистика на службе следствия. - 1956. - Вып. 7. - С. 153-164.

5 Див.: Колмаков В. П. Научная конференции по работам, выполненным в 1955 году : тезисы докл. / В. П. Колмаков, А. Н. Колесниченко. — Х. : Изд-во Харьк. гос. ун-та, 1956. - С. 11 . 
довжувалися дослідження 3 комплексного застосування слідчих дій ${ }^{1}$ та оперативно-розшукових заходів ${ }^{2}$ при плануванні початкового етапу розслідування ${ }^{3}$. Проте загальнотеоретичні засади реалізації цих комплексів поки що залишалися поза увагою науковців.

У 70-90-ті pp. минулого століття у вітчизняній криміналістиці спостерігаються тенденції інтенсифікації наукових досліджень і передусім щодо формування іï загальної теорії та окремих криміналістичних учень. Як зазначав Р. С. Бєлкін, у ці роки в криміналістиці з'являється низка перспективних теоретичних концепцій, що мали всі підстави в недалекому майбутньому досягти рівня окремих криміналістичних теорій. Це концепції криміналістичної характеристики злочину, слідчої ситуації, тактичних комбінацій (операцій), тактичного рішення й тактичного ризику4

Формування загальної теорії криміналістики дало змогу активізувати науковий пошук учених у двох напрямах: а) розроблення нових окремих криміналістичних теорій (учень); б) подальше дослідження й удосконалення вже відомих науці та практиці концепцій, право на існування яких уже доведено часом.

Зазначені процеси підштовхнули А. В. Дулова до ідеї тактичних операцій ${ }^{5}$. Він по праву вважається «батьком» цієї концепції, основним ії̈ фундатором і розробником. Саме А. В. Дулов у квітні 1972 р. на науковій конфе-

1 Див.: Белкин Р. С. Теория и практика следственного эксперимента / Р. С. Белкин. - М. : Высш. шк. МВД РСФСР, 1959; Васильев А. Н. Тактика допроса обвиняемых по делам о хищениях социалистической собственности / А. Н. Васильев // Сов. криминалистика на службе следствия. - 1953. - Вып. 5. - С. 3-42; Голунский С. А. Допрос на предварительном следствии / С. А. Голунский. - Ашхабад : Военноюридическая академия РККА, 1942; Карнеева Л. М. Тактика допроса / Л. М. Карнеева, С. С. Ордынский, С. Я. Розенблит. - М. : Госюриздат, 1958; Кочаров Г. И. Опознание на предварительном следствии : пособие для следователей / Г. И. Кочаров. - М. : Госюриздат, 1955; Колмаков В. П. Тактика производства следственного осмотра и следственного эксперимента / В. П. Колмаков. - Х. : Изд-во Харьк. гос. ун-та, 1956; Кривищкий С. Г. К вопросу о психологии свидетельских показаний и тактике допроса свидетелей : уч. зап. / С. Г. Кривицкий. — Львов, 1949. — Вып. 1. T. XIV. - C. 21-37; Цветков П. П. Опознание в стадии предварительного следствия / П. П. Цветков. - Л. : Изд-во ЛГУ, 1957 та ін.

2 Див.: Попов В. И. Розыскная работа следователя : пособие для следователей / В. И. Попов. - М. : Госюриздат, 1950; Колесниченко А. Н. Розыск / А. Н. Колесниченко // Сов. криминалистика. - М. : Профиздат, 1959. - С. 307-315; Богданов Б. Е. Розыск // Криминалистика: учебник / Б. Е. Богданов. - М. : Изд-во МГУ, 1963. С. 453-466 та ін.

Див.: Васильев А. Н. Планирование расследования преступлений / А. Н. Васильев, Г. Н. Мудьюгин, Н. А. Якубович. - М. : Госюриздат, 1957. - С. 90-103.

4 Див.: Белкин Р. С. История отечественной криминалистики / Р. С. Белкин. М. : НОРМА, 1999. - С. 273.

5 Див.: Дулов А. В. О разработке тактических операций при расследовании преступлений / А. В. Дулов // 50 лет советской прокуратуры и проблемы совершенствования предварительного следствия. - Л. : Ин-т усовершен. следств. работников прокуратуры и МВД, 1972. - С. 23-27. 
ренції виступив із доповіддю, у якій звернув увагу на те, що тактика не повністю відповідає потребам слідчої діяльності, оскільки вона в основному обмежується розробленням тактичних рекомендацій стосовно проведення окремих слідчих дій, у той час як слідчому досить часто доводиться вирішувати завдання, де необхідно застосовувати відповідні комплекси слідчих, оперативно-розшукових, ревізійних та інших дій. Виходячи із цього виникає нагальна потреба в розробленні цих комплексів, які А. В. Дулов запропонував називати «тактичні операції». При цьому, на думку науковця, досліджувати цю нову криміналістичну категорію слід у самостійному розділі слідчої тактики. Так поставити питання було принципово новим підходом до вирішення проблеми оптимізації розслідування злочинів шляхом застосування тактичних операцій, спрямованих на вирішення проміжних завдань за рахунок комплексного застосування системи слідчих дій, оперативно-розшукових та інших заходів.

У лютому 1973 р. на IX Міжнародному криміналістичному симпозіумі соціалістичних країн у Берліні з доповіддю «Раціоналізація та стандартизація в криміналістиці» виступив німецький криміналіст К. Шпіндлер (НДР). На його думку, незважаючи на розмаїття кримінальних подій, індивідуальність розслідування кожного конкретного випадку, усі можливі комплекси слідчих дій можна поділити на класи операцій з різним поставленням цілей. Такі комплекси дій було названо «криміналістичні стандартні ситуації (криміналістичні тактичні операчії (курсив наш. - В. Ш.). Підгрунтям для розроблення таких програм-інструкцій мають бути результати аналізу криміналістичної практики з урахуванням науково-обгрунтованих критеріїв. Тому процес розслідування доцільно поділити на відносно самостійні частини й визначати типові для них операщиї (курсив наш. $-B$. Ш.), методи та способи вирішення проблем, що можуть виявити себе в практичній діяльності ${ }^{1}$.

У подальшому ідею тактичних операцій підтримали вітчизняні вченікриміналісти I. М. Лузгін, В. І. Шиканов, Л. Я. Драпкін та ін. ${ }^{2}$ У 1979 р. побачила світ монографія А. В. Дулова «Тактичні операції при розслідуванні злочинів» ${ }^{3}$, яка підвела певні підсумки дослідження цієї важливої проблеми. У ній обгрунтовується необхідність розроблення тактичних операцій, виходячи з потреб криміналістичної теорії та слідчої практики, оскільки цілком очевидно, що неможливо обмежуватися розробленням рекомендацій

1 Див.: Шпиндлер К. Рационализация и стандартизация в криминалистике (отдельный оттиск) / К. Шпиндлер // IX Междунар. криминалист. симп. соц. стран. Берлин, 1973.

2 Див.: Лузгин И. М. Методологические проблемы расследования / И. М. Лузгин. - М. : Юрид. лит., 1973. - С. 109; Шиканов В. И. Информация к тактической операции «Атрибуция трупа» / В. И. Шиканов. - Иркутск : Изд-во Иркут. ун-та, 1975; Драпкин Л. Я. Особенности информационного поиска в процессе расследования и тактика следствия // Проблемы повышения эффективности предварительного следствия : тезисы науч.-практ. конф. / Л. Я. Драпкин. — Л. : Ин-т усовершен. следств. работников прокуратуры и МВД, 1976. - С. 54.

3 Див.: Дулов А. В. Тактические операции при расследовании преступлений / А. В. Дулов. - Мн. : Изд-во БГУ, 1979. 
лише 3 проведення окремих слідчих дій, а слід застосовувати їх комплекси, які багато в чому є типовими й повторюються у своїх основних параметрах. Певним здобутком цього періоду можна вважати міжвузівський збірник наукових праць «Тактичні операції та ефективність розслідування», що містив різні визначення й погляди на сутність і призначення категорії «тактична операція» ${ }^{1}$. Отримані результати дали підстави дійти висновку, що розроблення теорії тактичних операцій полегшує вирішення таких проблем криміналістики, як: а) алгоритмізація процесу розслідування; б) урахування й використання слідчої ситуації при розслідуванні; в) використання положень наукової організації праці слідчого; г) уживання дійових заходів для подолання протидії розслідуванню.

Починаючи з 90-х рр. і до сьогодні спостерігається помітне підвищення наукового та практичного інтересу до проблем розроблення й використання тактичних операцій, про що свідчить низка дисертацій, монографій, науково-практичних посібників, у яких розглядаються зазначені питання. Практично у всіх підручниках і навчальних посібниках із криміналістики останніх років тактичні операції висвітлюються або в окремих розділах (підрозділах), або розглядаються як самостійний елемент структури криміналістичної методики розслідування певної категорії злочинів. Ураховуючи зазначені обставини, можна констатувати, що сьогодні відбувається процес поглиблення формування криміналістичної теорії тактичних операцій і більш широкого впровадження цих організаційно-тактичних засобів у судово-слідчу практику.

Крім того, аналізування криміналістичної літератури з досліджуваної проблематики дає підстави дійти висновку, що серед науковців намітилися дві тенденції - традиційна й новаторська. Представники першої (А. В. Дулов, Л. Я. Драпкін, В. І. Шиканов, Є. П. Іщенко та ін.) продовжують відстоювати раніше висловлені ними погляди на сутність, природу й призначення тактичних операцій, уточнюючи окремі положення, які, як правило, суттєво не змінюють основного змісту раніше висловлених думок. Друга група науковців (О. Я. Баєв, І. М. Комаров, О. Є. Космодем' янська, Н. В. Кручиніна, В. О. Образцов, С. Б. Россінський, С. Ю. Якушин та ін.) намагаються по-новому підійти до тлумачення поняття тактичних операцій, пропонуючи новаторські підходи до їх формування й застосування при розслідуванні злочинів.

Таким чином, за тривалу історію розвитку криміналістичних знань проведені дослідження тактичних операцій мають важливе значення. Водночас аналізування наукових досягнень з розглядуваної проблеми свідчить про певну диспропорцію між рівнем теоретичних розробок і питань практичноприкладної спрямованості. Справа в тому, що вчені-криміналісти, за відсутності методологічних основ концепції тактичних операцій і одностайності щодо ключових питань теорії та практики їх реалізації, «самовіддано кинулися» розробляти типові тактичні операції й активно їх впроваджувати в практику розслідування злочинів, у тому числі й засобами комп’ютерної техніки.

1 Див.: Тактическая операция и эффективность расследования : сб. науч. тр. Свердловск : Изд-во СЮИ, 1986. 
Викликано це низкою причин, серед яких однією з найважливіших є відсутність розвиненої наукової концепції тактичних операцій, викладеної у сформованій окремій криміналістичній теорії. Ця обставина дещо уповільнює процеси подальшого дослідження цієї проблематики, робить їх недостатньо повними та такими, що не відповідають сучасному рівню розвитку криміналістики. Сьогодні дискусійним залишається переважна більшість питань, які $\epsilon$ визначальними у формуванні криміналістичної теорії тактичних операцій, зокрема, щодо сутності цих організаційно-тактичних засобів, їх функцій, принципів формування й реалізації, класифікації, побудови структури, визначення місця в системі криміналістики та процесі розслідування злочинів, виокремлення чинників-детермінантів, що зумовлюють розроблення типових тактичних операцій, а також здійснення їх організації й планування при розслідуванні злочинів. На ці та багато інших проблемних питань необхідно дати аргументовані відповіді, спираючись на грунтовні методологічні засади 3 урахуванням сучасних наукових концепцій у криміналістичній науці.

Отже, тактичні операції у своєму розвитку пройшли складний еволюційний шлях - від окремих посилань до формування відповідної наукової концепції, яка поступово трансформується в самостійну криміналістичну теорію (учення), що істотно збагачує науковий потенціал криміналістики та практики розслідування злочинів і судового провадження.

\section{РАЗВИТИЕ НАУЧНЫХ ПРЕДСТАВЛЕНИЙ О ТАКТИЧЕСКИХ ОПЕРАЦИЯХ}

\section{Шевчук В. М.}

Исследована история возникновения и становления криминалистической категории «тактическая операция». Генезис тактических операций исследуется в двух направлениях: теоретическом (как научная категория криминалистики) и практическом (как средство практической деятельности следственных органов). Изучение истории тактических операций осуществляется с учетом факторов-детерминантов, влияющих на процесс возникновения и формирования этой криминалистической категории. Предложены перспективные направления дальнейших научных исследований рассматриваемой проблематики.

Ключевые слова: генезис, тактические операции, тактические комбинации, история тактических операций, эволючионный путь развития тактических операций, криминалистическая теория тактических операчий.

\section{THE DEVELOPMENT OF SCIENTIFIC IDEAS ABOUT TACTICAL OPERATIONS}

Shevchuk V.M.

The article studies the creation and development of the criminalistic category of a «tactical operation». The genesis of tactical operations is investigated along two avenues: theoretical (as a scientific category within criminalistics) and 
practical (as a means of practical functioning of investigation bodies). The article provides its analysis of tactical operations with regard to determining factors that influenced the creation and development of this criminalistic category. It investigates into the problems of determining stages in the tactical operations development history and their formation as a scientific criminalistic category as well as a comprehensive tactical tool of practical application in criminal proceedings. The emergence, formation and introduction of arrays of investigation actions, operation and search measures, tactical operations in the forensic and investigation practices are closely connected with the establishment of criminalistics as an independent area of knowledge. Research into the history of emergence and formation as well as the present state and perspectives for the development of tactical operations is necessary to form the concepts of this criminalistic category, determine its nature, essence, theoretical significance and practical application. The article concludes with suggesting perspective areas for further scientific research into the given problems.

Keywords: genesis, tactical operations, tactical combinations, history of tactical operations, evolutionary way of tactical operations development, criminalistic theory of tactical operations.

О. Ю. Булулуков, доцент кафедри криміналістики Національного юридичного університету імені Ярослава Мудрого, кандидат юридичних наук

\section{ТРАНСФОРМАЦІЯ СЛІДЧИХ ПОМИЛОК У КРИМІНАЛЬНОМУ СУДОЧИНСТВІ}

Розглянуто судові помилки й фактори, щуо впливають на їх виникнення. Визначено види трансформачї̈ помилок при прийнятті тактичних рімень слідчим у судові помилки. Проаналізовано роль $і$ значення внутрішнього переконання судді в трансформації слідчих помилок.

Ключові слова: трансформація помилок, судова помилка, внутрішне переконання суддi.

У процесі розгляду матеріалів кримінального провадження в суді можуть бути встановлені помилки, допущені слідчим при прийнятті тактичних рішень. Зазначені помилки впливають на оцінювання судом доказів, зібраних при проведенні слідчих дій. У системі доказів, сформованій при розслідуванні злочинів, виявлені в ході судового слідства помилки сприймаються залежно від їх впливу на цілісність цієї системи. Сприйняття (несприйняття) даної помилки та здійснення на їі основі судової - суть трансформації помилки при прийнятті тактичного рішення в судову помилку. Наявність судових помилок у кримінальному судочинстві негативно впливає на ефективне здійснення правосуддя. 